\title{
$A b$ initio modelling of calcium phosphate clusters and their vibrational spectra
}

\author{
I.E.Boldeskul ${ }^{1}$, L.F.Sukhodub ${ }^{1}$, A.N.Kalinkevich ${ }^{1}$, V.D.Khavryutchenko ${ }^{2}$ \\ 1 Institute of Applied Physics, National Academy of Sciences of Ukraine, \\ 58 Petropavlovskaya Str., 40030 Sumy, Ukraine \\ 2 Institute of Sorption and Problems of Endoecology, National Academy of Sciences of Ukraine, \\ 13 General Naumov Str., 03164 Kiev, Ukraine
}

Received March 29, 2006, in final form June 20, 2006

\begin{abstract}
Calcium phosphate and hydroxylcalcium phosphate clusters that model amorphous phase elementary unit cells as well as their vibrational spectra were calculated by ab initio quantum chemical method using GAMESS code. Normal coordinate analysis was accomplished for phosphate anion, tricalcium phosphate and hydroxylapatite. Calculated IR-spectra and spectra of inelastic neutron scattering were defined in comparison with experimental data. It was shown that within the suggested approach, vibrational spectroscopy appears to be a reliable method of verifying the quantum chemical calculated structure versus the experimental data.
\end{abstract}

Key words: molecular simulation, cluster approximation, calcium phosphate, hydroxyapatite, normal coordinate analysis

PACS: $31.15 . A r, 61.46 . B c, 87.68 .+z, 87.15 .-v$

\section{Introduction}

Nonstochiometry of $\mathrm{Ca} / \mathrm{P}$ ratio in synthetic calcium hydroxylapatite (Ca-HAP) used in biomedical materials is well known and is due to heterogeneous minor phases, such as polymorphic tricalcium phosphate (TCP), TCP-hydroxide, oxide-, hydroxide- and carbonate-calcium: CaO, $2 \mathrm{Ca}(\mathrm{OH})_{2}, \mathrm{CaHPO}_{2}, \mathrm{Ca}_{3}\left(\mathrm{PO}_{4}\right)_{2}, 3\left[\mathrm{Ca}_{3}\left(\mathrm{PO}_{4}\right)_{2}\right], \mathrm{Ca}_{10}\left(\mathrm{PO}_{4}\right)_{6}(\mathrm{OH})_{2}$, etc. [1,2].

Complex phase composition and mutual transformation of components require a simultaneous application of different physical techniques for correct structure formation in the synthesis and for adequate description of the product. These phases can be identified using X-ray scattering and spectroscopy analysis within its threshold range [3-5]. Mass spectrometry $[6,7]$ and vibrational spectroscopy used with the aim of an express control in chemical synthesis, as well as for the analysis of native bone tissue $[8,9]$ seem to be more sensitive techniques.

Characterization of vibrations and the peculiarities of spectral and structural behaviour of phosphate- and calcium ions, including hydroxyl functional groups, as well as their sensitivity to intra- and intermolecular interactions, crystal effects including, allow us to suggest an effective application of vibrational spectroscopy for cluster formation analysis. Informativity of vibrational FTIR- and Raman-spectra including microspectroscopy rises due to the application of new experimental techniques, such as inelastic neutron scattering (INS) spectroscopy, increases the reliability of the spectra band assignment, especially for all vibrations with high level of hydrogen atom participation.

Modern computational chemistry permits the modelling of the above mentioned states and their spectra. The aim of the present work is computer modelling of the mentioned molecular clusters and vibrational spectra of such clusters in their relevance to experimental data. 


\section{Methodology}

Literature data on quantum chemical calculations of the calcium containing compounds are not numerous. There are numerous methods of modelling the space structure at the atomic level. Therefore it is difficult to choose the best quantum chemical method of computing a big set of calcium-phosphate based compounds with different structure and their vibration spectra. The main question that arises during the modelling process is how to verify the obtained structure. This question becomes a big problem for small particles, amorphous or real surface under study, when it is impossible to use standard structure methods such as X-ray or neutron diffraction. In order to solve this problem we proposed to use vibration spectroscopy as a method of verifying and comparing the calculated and real structures.

For quantum chemistry modelling we applied ab initio methodology with PC-GAMESS program package [10]. All computations were performed up to a complete structure optimization, Cartesian force field evaluation, dipole moment and polarizability derivatives calculation. Normal coordinate analysis in internal dependant coordinate system was performed by means of methods, algorithms and software used earlier [11], but we should remind the basic principles of this methodology and utilization.

The force constant matrix in Cartesian coordinates after GAMESS program was converted to internal dependant coordinate system. Inverted vibration task or force field fitting was solved using a full-matrix method. Inelastic neutron spectra intensity was calculated using the known neutron coherent and incoherent cross-section on atomic nucleus with their natural isotope ratio. For the INS intensity calculation the form of normal vibrations was used. After solving a direct vibration problem in internal dependant coordinate system, the form of normal vibrations was transformed to Cartesian coordinates and gave us atom deviation amplitudes. Multiplying derivatives (of dipole moments or polarizability) by the atom deviation amplitudes one can obtain the alteration of the total dipole moment or polarizability for the current normal vibration. The square of this alteration is proportional to the absolute intensity in IR- or Raman spectra. The intensity in INS spectra is calculated similarly, but separately for coherent and incoherent parts of total neutron cross-section of every normal vibration.

Therefore, the intensity calculation leads to the delta-function which shows the position and intensity of normal vibration. Due to the lack of suitable theory of the vibration band shape, the theoretical vibrational spectra were obtained as the sum of Gauss-like lines normalized to $100 \%$ with pre-exponential coefficient equal to the computed intensity, the position equal to the computed normal vibration frequency and halfwidth being defined by the type of the spectrum and after building the theoretical spectrum, the value of the halfwidth was slightly varied for better agreement with the experiment.

For INS spectra the halfwidth was taken as the known apparatus function and for IR- and Raman spectra the starting value was taken $10 \mathrm{~cm}^{-1}$. Experimental spectra, which were taken from the literature, were scanned, digitized and used to compare with theoretical spectra and to solve inverted vibration problems.

Table 1. Space and electronic structure data for phosphate anion.

\begin{tabular}{|c|c|c|c|}
\hline Parameter & MINI basis set & MINI- $\mathrm{d} 1$ basis set & STO-6-311 basis set \\
\hline $\mathrm{P}-\mathrm{O}$ bond length in $\AA$ & 1.8095 & 1.5878 & 1.6409 \\
\hline $\mathrm{P}-\mathrm{O}$ bond order & 0.945 & 1.517 & 1.091 \\
\hline Charge on $\mathrm{P}$ & 0.5560 & 0.4510 & 1.8463 \\
\hline Charge on $\mathrm{O}$ & -0.8890 & -0.8627 & -1.2116 \\
\hline
\end{tabular}

The results of quantum chemical calculation will be given in table 1 . We used some basis sets (MINI without polarization d-function, MINI-d1 with one polarization d-function and STO-6-311) for the ab initio calculation, which is introduced into GAMESS-PC program. They are well known and therefore we shall not discuss them. At first, we should discuss the building "brick" for all 
phosphate compounds - phosphate anion $\mathrm{PO}_{4}^{-3}$. To test methodology and to obtain scaling factors for the phosphate anion, we performed the calculation for the ideal tetrahedral anion $\mathrm{PO}_{4}^{-3}$. The space and electronic structure data for phosphate anion are presented below.

After data evaluation for the normal coordinate analysis in internal dependant coordinate system inverted vibrational problem was solved for these three data sets, using literature data [12]. Experimental frequencies for the ideal tetrahedral anion $\mathrm{PO}_{4}^{-3}$ are: $\nu_{1}=938 \mathrm{~cm}^{-1}, \nu_{2}=420 \mathrm{~cm}^{-1}$, $\nu_{3}=1017 \mathrm{~cm}^{-1}, \nu_{4}=567 \mathrm{~cm}^{-1}$.

After force field fitting the calculated and experimental frequencies are congruent with high accuracy (deviation is less than $0.1 \mathrm{~cm}^{-1}$ ). Force constants are listed in table 2 .

Table 2. Force constants.

\begin{tabular}{|c|c|c|c|c|c|c|}
\hline Force constant & MINI & MINI-d1 & $\begin{array}{l}\text { STO } \\
6-311\end{array}$ & $\begin{array}{l}\text { Fitted } \\
\text { MINI }\end{array}$ & $\begin{array}{l}\text { Fitted } \\
\text { MINI- } \\
\text { d1 }\end{array}$ & $\begin{array}{l}\text { Fitted } \\
6-311\end{array}$ \\
\hline $\mathrm{K}(\mathrm{P}-\mathrm{O})$ & 3.3965 & 11.0926 & 8.1674 & 9.6522 & 9.7085 & 9.6877 \\
\hline $\mathrm{K}(\mathrm{P}-\mathrm{O} / \mathrm{P}-\mathrm{O})$ & -0.2680 & 0.6651 & 0.2806 & 1.0954 & 1.0766 & 1.0835 \\
\hline $\mathrm{K}(\mathrm{O}-\mathrm{P}-\mathrm{O})$ & 1.4063 & 2.4303 & 2.1032 & 2.9504 & 1.9326 & 2.2458 \\
\hline $\mathrm{K}(\mathrm{P}-\mathrm{O} / \mathrm{O}-\mathrm{P}-\mathrm{O})$ & 0.0576 & 0.2957 & 0.2110 & 0.2402 & 0.2211 & 0.2267 \\
\hline $\mathrm{K}\left(\mathrm{P}-\mathrm{O}^{\prime} / \mathrm{O}-\mathrm{P}-\mathrm{O}\right)$ & -0.0547 & -0.2957 & -0.2110 & -0.2373 & -0.2211 & -0.2267 \\
\hline $\mathrm{K}(\mathrm{O}-\mathrm{P}-\mathrm{O} / \mathrm{O}-\mathrm{P}-\mathrm{O})$ & -0.2008 & -0.3194 & -0.2729 & -0.1562 & -0.3651 & -0.3021 \\
\hline $\mathrm{K}(\mathrm{O}-\mathrm{P}-\mathrm{O} / \mathrm{O}-\mathrm{P}-\mathrm{O})$ & -0.5979 & -1.1528 & -1.0117 & -0.8796 & -0.8930 & -0.8904 \\
\hline
\end{tabular}

These data show that in all cases the quantum force field needs to be scaled and/or it is necessary to solve the inverted vibration problem. For the fitted force fields the difference between the same force constant is small. It means that the method of fitting the force field is applicable and produces a good quality force field independently of the starting points. These force constants sizes are presented in $10^{6} \mathrm{~cm}^{-2}$. To convert the bond-bond force constant to mdin/ $\AA$ the value should be multiplied by factor of 0.6409891 , the bond-angle force constant being converted to mdin, the value should be multiplied by a factor of 0.6986781 and the angle -angle force constant converted to mdin $/ \AA$, the value should be multiplied by a factor of 0.7615592 . This result shows that ab initio method produces force constants with various accuracy depending on the basis set. However, in all cases the force field should be fitted using experimental frequencies or, better. At first it is needed to scale the field and then to fit it. Our experience shows that we can transfer the scaling factors for the same vibrational coordinate and for the same basis set to the row of the compounds with similar structure fragments.

\section{Results and discussion. Cluster models}

Calcium-phosphate based materials under our interest are usually manufactured by plasma spray or other chemical vapour deposition (CVD) process, which produces amorphous and/or nonstochiometric compounds. Since we started from the gas-phase, the crystal structure as an initial structure for simulation should be rejected [12].

As a starting point for space structure optimization one can start from the "free" ions $\mathrm{Ca}^{+2}$ and $\mathrm{PO}_{4}^{-3}$. If necessary, the hydroxyl ion was added to the initial ion gas phase mixture. We understand that this way of building the initial structure may lead to different minima on the potential energy surface (PES), but this way is free from a strict dictate of the crystal structure and is more preferable for amorphous solid simulation.

In a mathematical sense, no criterion guarantees that the global minimum has been found on the PES. Nonetheless, using chemical restriction that any of the considered isomers conserves two $\mathrm{PO}_{4}$-groups in which the phosphorous atom is surrounded by four oxygen atoms, we can perform a systematic search on the PES by enumerating all the different topologies, that is, the different ways of connecting calcium and oxygen atoms, encountered in $\mathrm{Ca}_{3}\left(\mathrm{PO}_{4}\right)_{2}$ clusters [13]. 
To investigate many minima energy hypersurfaces we developed a simple, but effective method, which was successfully tested on typical amorphous solid like high dispersed silica and silica glasses [11]. These results will be presented in the article to follow [14].

Therefore, hereinafter, we describe the simplest calcium-phosphate clusters, which can become building blocks for amorphous and glass-like apatites and their derivatives.

Simplest calcium-phosphate clusters with formula $\mathrm{Ca}_{3}\left(\mathrm{PO}_{4}\right)_{2}$ are shown in figures 1 and 2 of table 3. At this stage the mentioned cluster was taken as a reference model, because this system is commonly considered to be an elementary unit cell of amorphous phase and is known in literature [13]. This work discusses 89 ab initio starting geometries corresponding to different topologies of combining three calcium cations and two phosphate anions. The calculated and experimental IR-, Raman and INS-spectra of the clusters are presented in tables 4 and 5 .

Table 3. Spatial structure of some calcium-phosphate clusters.

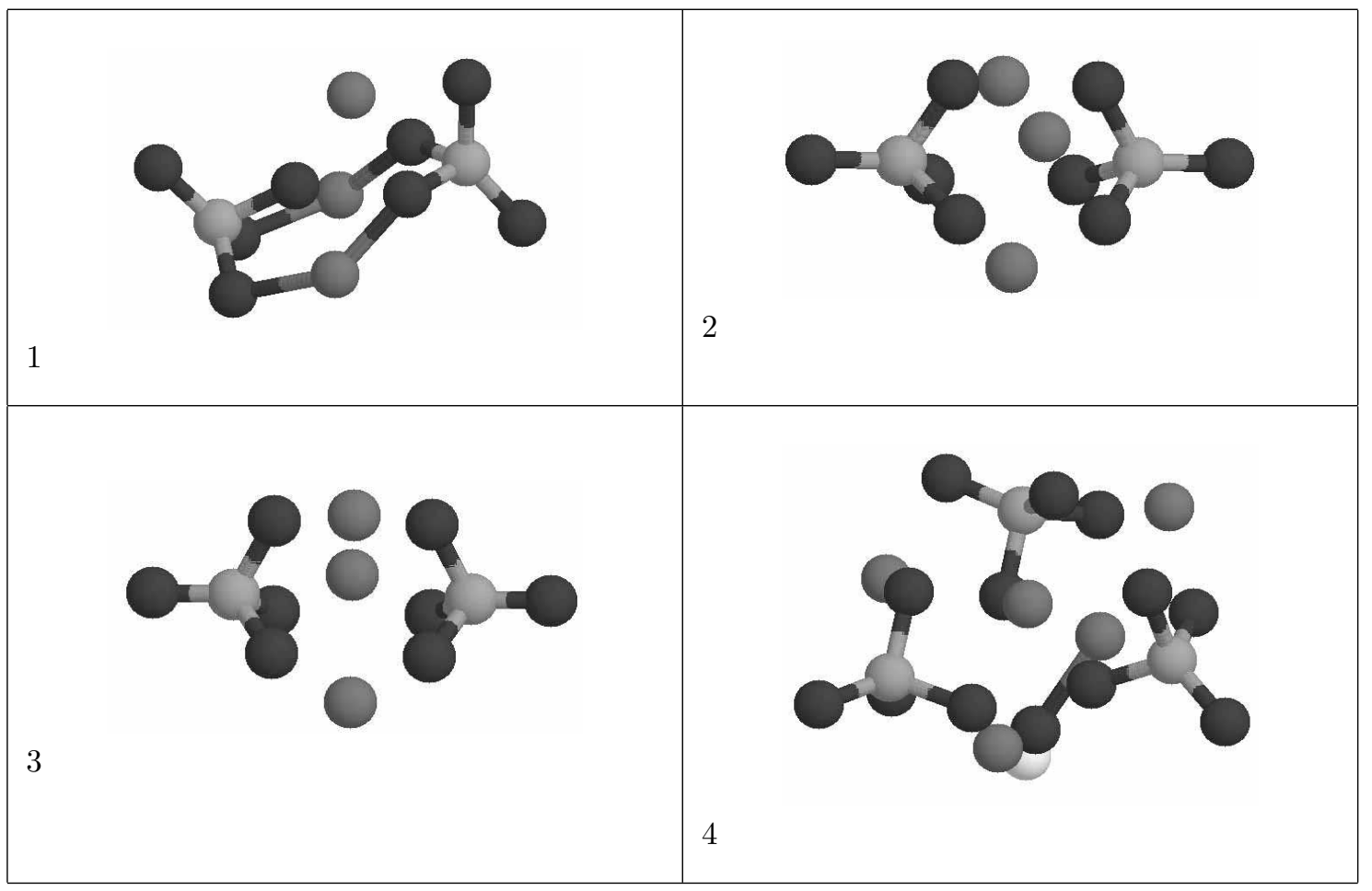

The most stable structure, $\mathrm{Ca}_{3}\left(\mathrm{PO}_{4}\right)_{2}$ cluster (table 3, figure 2), is also known. Our results for two clusters (table 3, figures 1-2) are in good agreement with the literature results [13]. Symmetrical structure was calculated using two basis sets: clusters 2 with basis set MINI and cluster 3 with basis set MINI_d1 (one additional polarization d-function for every atom). More stable structure D3h symmetry with all three calcium atoms bridging two $\mathrm{PO}_{4}$ groups is shown in figure 2 of table 3. It is $92.93 \mathrm{kcal} / \mathrm{mol}$ (basis set MINI) which is more preferable than structure figure 1. The bond length between calcium ions and the oxygens nearest to $\mathrm{PO}_{4}^{-3}$ is close to the sum of Wan-der-Waals radii of these atoms. These distances are in between the limits $2.18-2.36 \AA$ while bond orders are within $0.129-0.235$. It is interesting to note that there is no linear relationship between bond length and bond order for $\mathrm{Ca}-\mathrm{O}$ bonds. Detailed data for these two clusters $(2$ and 3) are presented in table 6 .

All bonds in the clusters are usual ones. These data show that the chemical bond between calcium ions and the nearest oxygen is mainly ionic. It leads to a very important conclusion that calcium phosphate structure should be very sensitive to the environment and should form an amorphous phase very easily. 
Table 4. Vibrational spectra (INS, IR- and Raman) of the some calcium-phosphate clusters.

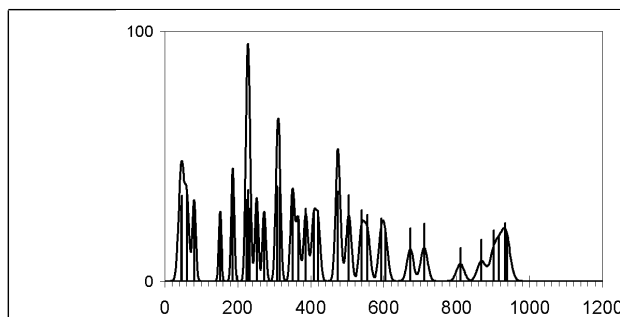

1. Cluster 1. Theoretical INS spectrum.

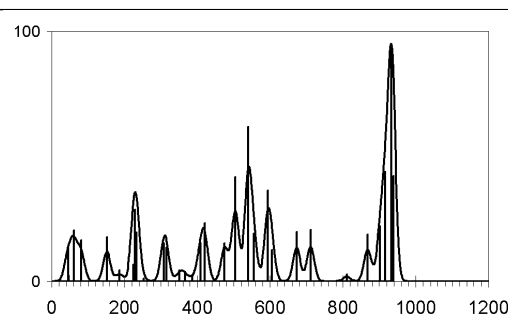

2. Cluster 1. Theoretical IR spectrum.

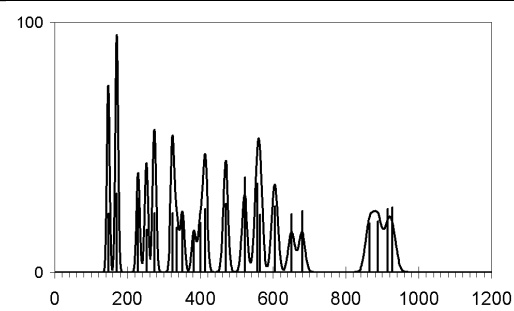

4. Cluster 2. Theoretical INS spectrum.

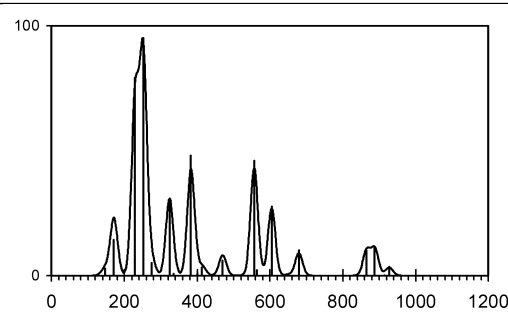

6. Cluster 2. Theoretical Raman spectrum.

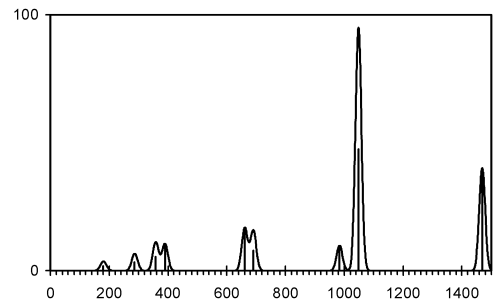

8. Cluster 3. Theoretical IR spectrum.

7. Cluster 3. Theoretical INS spectrum.

The vibrational spectra calculated for these structures in the phosphate ion vibration region are presented in figure 3 of table 4 . It is evident that vibration frequencies $\nu(\mathrm{PO})$ are under $1000 \mathrm{~cm}^{-1}$ (except basis set MINI_d1) and together with the calculated quantum chemical parameters, such as interatomic distance and their charges show ionic character of the bond. For a less symmetrical structure (2) as well as for the calculated inelastic neutron scattering spectra (INS) the calculations demonstrate more peaks due to the elimination of the prohibition by symmetry rules.

Similarly, more complex 3D model of $3\left[\mathrm{Ca}_{3}\left(\mathrm{PO}_{4}\right)_{2}\right]$ cluster was built from three clusters $(2)$. Complete optimization of geometry leads to the structure whose main difference from the initial structure is the increase of calcium-oxygen distance. It leads to the non-bonding of the calcium ions 
Table 5. Vibrational spectra (INS, IR- and Raman) of some calcium-phosphate clusters. (Continue.)

\begin{tabular}{|c|c|}
\hline $\begin{array}{l}\text { 9. Cluster 3. Theoretical Raman spectrum. } \\
\text { 9. The }\end{array}$ & $\begin{array}{l}\text { 10. Cluster 4. Theoretical (1) and experimen- } \\
\text { tal (2) [15] INS spectrum. }\end{array}$ \\
\hline $\begin{array}{l}\text { 11. Cluster 4. Theoretical (1) and experimen- } \\
\text { tal (2) [15] IR spectrum. }\end{array}$ & $\begin{array}{l}\text { 12. Cluster 4. Theoretical (1) and experimen- } \\
\text { tal (2) [15] IR spectrum. }\end{array}$ \\
\hline $\begin{array}{l}\text { 13. Cluster 4. Theoretical (blue and black) } \\
\text { and experimental [15] (red) Raman spectrum. }\end{array}$ & \\
\hline
\end{tabular}

with the nearest oxygenes since this distance is larger than the sum of Van-der-Waals radii of these atoms. Bond orders between calcium ions and the nearest oxygenes are less than 0.170, but their numbers are large. This means that the bond orders decrease, while the number of contacts to calcium increases. Total bond order for every calcium ion is between 0.537 and 0.576 . This corresponds to calcium coordination number 4 to 5 , that is not typical of calcium ions, which may be up to 12 -fold coordinated. These data show that covalent part of calcium-phosphate ion interaction is not big enough and non-directional and unsaturable electrostatic ionic bonds should play an important role in calcium phosphate interactions. It means that these kinds of compounds should easily turn into amorphous phase. Vibrational spectra of such a system are being calculated at the moment.

Finally cluster 4 shows the simplest HAP system with formula unit $\mathrm{Ca}_{5}\left(\mathrm{PO}_{4}\right)_{3}(\mathrm{OH})$ and its calculated vibrational spectra. Literature data [15] on IR and INS spectra make it possible to specify the calculated spectrum up to a full agreement with the experiment by solving a reverse spectral task. Normally coordinated analysis makes up for assigning vibrational frequencies (table 7) and shows characteristic properties of HAP structure. Despite the smallest cluster size this system can reproduce the main features of experimental spectra: INS, IR and Raman. Experimental data utilization enables us to make a correct vibration spectra assignment based on the 
Table 6. Structure and electronic characteristics for clusters 2 and 3.

\begin{tabular}{|c|c|c|}
\hline Parameter & Basis set MINI & Basis set MINI_d1 \\
\hline $\mathrm{P}-\mathrm{O}$ bond length $(\AA) /$ bond order & $1.730 / 0.902$ & $1.609 / 1.270$ \\
\hline $\mathrm{P}=\mathrm{O}$ bond length $(\AA) /$ bond order & $1.696 / 1.103$ & $1.472 / 1.925$ \\
\hline $\mathrm{Ca}-\mathrm{O}$ bond length $(\AA) /$ bond order & $2.312 / 0.150$ & $2.311 / 0.273$ \\
\hline$\angle \mathrm{O}=\mathrm{P}-\mathrm{O}$ angle (degree) & 120.8 & 116.9 \\
\hline$\angle \mathrm{O}-\mathrm{P}-\mathrm{O}$ angle (degree) & 96.12 & 101.14 \\
\hline $\mathrm{Q}_{\mathrm{Ca}}$ & 1.593 & 1.348 \\
\hline $\mathrm{Q}_{\mathrm{P}}$ & 0.945 & 0.717 \\
\hline $\mathrm{Q}_{\mathrm{O}-}$ & -0.901 & -0.709 \\
\hline $\mathrm{Q}_{\mathrm{O}=}$ & -0.631 & -0.610 \\
\hline
\end{tabular}

intensity calculations. Using the big difference between the nature of the band intensity for these three kinds of experimental vibrational spectra and their identity with normal vibration forms we can divide the vibrational spectra into two groups: below $800 \mathrm{~cm}^{-1}$ and above. Between $800 \mathrm{~cm}^{-1}$ and $1300 \mathrm{~cm}^{-1}$ one can observe the vibrations and a corresponding band, which can be assigned to the phosphate ion internal vibrations $-\mathrm{P}-\mathrm{O}$ bond stretch symmetrical and antisymmetrical vibrations. Due to the decrease of the phosphate ion local symmetry in the real solids from ideal Td, strong selection rules (for IR- and Raman spectroscopy) are broken and one can observe all bands and their splitting due to the disappearance of degeneration. As a result, the experimental spectrum after removing all the faults turns out to be an envelope curve or the sum of all normal vibration bands. Therefore, one can use this spectral region to detect the phosphate ion status.

The spectral region between $400 \mathrm{~cm}^{-1}$ and $800 \mathrm{~cm}^{-1}$ can be used to detect the $\mathrm{O}-\mathrm{P}-\mathrm{O}$ angle bending vibrations. These kinds of vibrations are more sensitive to the chemical environment and space structure transformation due to $\mathrm{Ca}-\mathrm{O}$ bonds and their force constants involve more participants in these vibrations. Therefore, this region can be used in investigating the calcium ion position and in coordinating the polyhedron transformation. However, this requires additional cluster investigations.

Also the spectral region below $400 \mathrm{~cm}^{-1}$ can be used in investigating the cluster packing and the bonding between phosphate-calcium aggregates. However, we need good quality INS, IR- and Raman spectra for this region in order to build spectra-structure relationships and understand their nature. Without quantum chemical calculation and a complete normal-coordinate analysis these relations and rules, which are used in the industrial quality control, should be empirical speculations only.

It means that vibration spectroscopy should be a beneficial method of controlling and testing in calcium-phosphate systems. We hope that further elaborate investigations in this field will lead us to a deep comprehension of how to control and manage the structure and properties of calciumphosphate systems.

\section{Conclusions}

Calculations of vibrational frequencies in IR-, Raman- and INS-spectra supplemented by intensity computation within one force field and structure under investigation ensure better assignment of experimental data.

The modelling of the calcium-phosphate cluster properties, first of all their vibrational spectra, with GAMESS code followed by comparison with experiment shows that MINI basis set appears to be a good compromise between computational time and costs and accuracy of calculations.

The results of this study suggest that direct quantum chemical calculations and comprehensive assignment of wave numbers in vibrational spectra of the simple hydroxyapatite clusters can be helpful in analysing amorphous or microcrystalline nano-size calcium-phosphate systems. 
Table 7. Calculated normal vibration for the cluster $\mathrm{Ca}_{5}\left(\mathrm{PO}_{4}\right)_{3}(\mathrm{OH})$ - hydroxyapatite. Normal vibration notation: $\nu$ - stretch vibration, $\delta$ - angle deformation, $\rho$ - out-of-plane vibration, $\chi-$ torsion vibration, P.E.D. - potential energy distribution.

\begin{tabular}{|c|c|c|c|c|c|}
\hline No & Freq. $\mathrm{cm}^{-1}$ & $\begin{array}{l}\text { INS int. rela- } \\
\text { tive. }\end{array}$ & $\begin{array}{l}\text { IR int. rela- } \\
\text { tive. }\end{array}$ & P.E.D. $\%$ & Assignment \\
\hline 148 & 3735.00 & 100.00 & 14.45 & 99.94 & $\nu \mathrm{O}-\mathrm{H}$ \\
\hline 147 & 1112.66 & 2.24 & 34.34 & $\begin{array}{l}77.67 \\
11.18\end{array}$ & $\begin{array}{l}\nu \mathrm{P}-\mathrm{O} \\
\nu \mathrm{P}-\mathrm{O}\end{array}$ \\
\hline 146 & 1092.71 & 0.50 & 25.84 & $\begin{array}{l}9.17 \\
83.47\end{array}$ & $\begin{array}{l}\nu \mathrm{P}-\mathrm{O} \\
\nu \mathrm{P}-\mathrm{O}\end{array}$ \\
\hline 145 & 1073.64 & 96.00 & 35.77 & 51.34 & $\delta \mathrm{Ca}-\mathrm{O}-\mathrm{H}$ \\
\hline 144 & 1056.95 & 4.53 & 45.68 & 45.15 & $\nu \mathrm{P}-\mathrm{O}$ \\
\hline 143 & 1035.60 & 4.63 & 100.00 & 56.84 & $\nu \mathrm{P}-\mathrm{O}$ \\
\hline 142 & 1014.36 & 5.53 & 48.66 & $\begin{array}{l}67.32 \\
5.97 \\
8.42\end{array}$ & $\begin{array}{l}\nu \mathrm{P}-\mathrm{O} \\
\delta \mathrm{O}-\mathrm{P}-\mathrm{O} \\
\delta \mathrm{Ca}-\mathrm{O}-\mathrm{P}\end{array}$ \\
\hline 141 & 957.74 & 5.04 & 56.75 & 58.59 & $\nu \mathrm{P}-\mathrm{O}$ \\
\hline 140 & 934.53 & 1.34 & 55.70 & 49.97 & $\nu \mathrm{P}-\mathrm{O}$ \\
\hline 139 & 913.40 & 2.99 & 42.16 & $\begin{array}{l}67.68 \\
7.11\end{array}$ & $\begin{array}{l}\nu \mathrm{P}-\mathrm{O} \\
\delta \mathrm{O}-\mathrm{P}-\mathrm{O}\end{array}$ \\
\hline 138 & 892.09 & 4.35 & 37.32 & $\begin{array}{l}16.24 \\
50.39\end{array}$ & $\begin{array}{l}\nu \mathrm{P}-\mathrm{O} \\
\nu \mathrm{P}-\mathrm{O}\end{array}$ \\
\hline 137 & 869.26 & 1.03 & 19.21 & $\begin{array}{l}54.66 \\
6.68\end{array}$ & $\begin{array}{l}\nu \mathrm{P}-\mathrm{O} \\
\delta \mathrm{Ca}-\mathrm{O}-\mathrm{P}\end{array}$ \\
\hline 136 & 656.59 & 32.15 & 30.92 & 15.00 & $\nu \mathrm{P}-\mathrm{O}$ \\
\hline 135 & 637.96 & 60.29 & 15.73 & 38.50 & $\rho \mathrm{Ca}-\mathrm{O}-\mathrm{Ca}$ \\
\hline 134 & 636.54 & 37.98 & 23.88 & 19.79 & $\nu \mathrm{P}-\mathrm{O}$ \\
\hline 133 & 629.42 & 43.55 & 1.74 & 21.55 & $\rho \mathrm{Ca}-\mathrm{O}-\mathrm{Ca}$ \\
\hline 132 & 604.94 & 12.28 & 54.31 & $\begin{array}{l}14.74 \\
5.65 \\
32.66 \\
13.63\end{array}$ & $\begin{array}{l}\nu \mathrm{Ca}-\mathrm{O} \\
\nu \mathrm{Ca}-\mathrm{O} \\
\nu \mathrm{P}-\mathrm{O} \\
\nu \mathrm{P}-\mathrm{O}\end{array}$ \\
\hline 131 & 590.28 & 16.85 & 28.73 & $\begin{array}{l}12.46 \\
12.29 \\
5.28 \\
19.11 \\
6.55\end{array}$ & $\begin{array}{l}\nu \mathrm{Ca}-\mathrm{O} \\
\nu \mathrm{Ca}-\mathrm{O} \\
\nu \mathrm{Ca}-\mathrm{O} \\
\nu \mathrm{P}-\mathrm{O} \\
\delta \mathrm{O}-\mathrm{P}-\mathrm{O}\end{array}$ \\
\hline 130 & 579.71 & 14.74 & 7.23 & $\begin{array}{l}5.57 \\
19.75 \\
33.94\end{array}$ & $\begin{array}{l}\nu \mathrm{Ca}-\mathrm{O} \\
\nu \mathrm{Ca}-\mathrm{O} \\
\nu \mathrm{P}-\mathrm{O}\end{array}$ \\
\hline 129 & 568.31 & 4.62 & 34.69 & $\begin{array}{l}7.26 \\
7.42 \\
14.87\end{array}$ & $\begin{array}{l}\nu \mathrm{Ca}-\mathrm{O} \\
\nu \mathrm{P}-\mathrm{O} \\
\nu \mathrm{P}-\mathrm{O}\end{array}$ \\
\hline 128 & 565.47 & 7.70 & 10.69 & $\begin{array}{l}17.19 \\
14.98 \\
9.66\end{array}$ & $\begin{array}{l}\nu \mathrm{P}-\mathrm{O} \\
\nu \mathrm{P}-\mathrm{O} \\
\delta \mathrm{O}-\mathrm{P}-\mathrm{O}\end{array}$ \\
\hline 127 & 564.58 & 4.50 & 23.39 & $\begin{array}{l}6.41 \\
9.79 \\
5.77 \\
14.16 \\
6.24\end{array}$ & $\begin{array}{l}\nu \mathrm{Ca}-\mathrm{O} \\
\nu \mathrm{Ca}-\mathrm{O} \\
\nu \mathrm{Ca}-\mathrm{O} \\
\nu \mathrm{P}-\mathrm{O} \\
\nu \mathrm{P}-\mathrm{O}\end{array}$ \\
\hline
\end{tabular}




\begin{tabular}{|c|c|c|c|c|c|}
\hline 126 & 547.03 & 11.52 & 53.15 & $\begin{array}{l}13.44 \\
13.33 \\
15.11 \\
5.52 \\
13.04 \\
7.86\end{array}$ & $\begin{array}{l}\nu \mathrm{Ca}-\mathrm{O} \\
\nu \mathrm{Ca}-\mathrm{O} \\
\nu \mathrm{P}-\mathrm{O} \\
\delta \mathrm{O}-\mathrm{P}-\mathrm{O} \\
\delta \mathrm{O}-\mathrm{P}-\mathrm{O} \\
\delta \mathrm{Ca}-\mathrm{O}-\mathrm{P}\end{array}$ \\
\hline 125 & 526.66 & 15.02 & 20.24 & 20.41 & $\nu \mathrm{Ca}-\mathrm{O}$ \\
\hline 124 & 517.61 & 13.37 & 2.41 & 13.59 & $\nu \mathrm{Ca}-\mathrm{O}$ \\
\hline 123 & 513.70 & 6.55 & 9.35 & $\begin{array}{l}5.08 \\
22.28\end{array}$ & $\begin{array}{l}\nu \mathrm{Ca}-\mathrm{O} \\
\nu \mathrm{Ca}-\mathrm{O}\end{array}$ \\
\hline 122 & 496.60 & 6.42 & 10.63 & $\begin{array}{l}11.99 \\
6.78\end{array}$ & $\begin{array}{l}\nu \mathrm{Ca}-\mathrm{O} \\
\nu \mathrm{Ca}-\mathrm{O}\end{array}$ \\
\hline 121 & 474.24 & 14.84 & 5.75 & $\begin{array}{l}10.20 \\
5.53 \\
23.40 \\
5.86\end{array}$ & $\begin{array}{l}\nu \mathrm{Ca}-\mathrm{O} \\
\nu \mathrm{P}-\mathrm{O} \\
\delta \mathrm{O}-\mathrm{P}-\mathrm{O} \\
\delta \mathrm{Ca}-\mathrm{O}-\mathrm{P}\end{array}$ \\
\hline 120 & 462.53 & 9.14 & 7.38 & $\begin{array}{l}10.18 \\
6.74 \\
10.34 \\
6.33\end{array}$ & $\begin{array}{l}\nu \mathrm{Ca}-\mathrm{O} \\
\nu \mathrm{Ca}-\mathrm{O} \\
\nu \mathrm{P}-\mathrm{O} \\
\delta \mathrm{O}-\mathrm{P}-\mathrm{O}\end{array}$ \\
\hline 119 & 450.38 & 11.29 & 15.47 & 14.52 & $\nu \mathrm{Ca}-\mathrm{O}$ \\
\hline 118 & 424.41 & 3.86 & 3.81 & $\begin{array}{l}23.81 \\
16.93 \\
16.33 \\
6.27\end{array}$ & $\begin{array}{l}\nu \mathrm{Ca}-\mathrm{O} \\
\nu \mathrm{P}-\mathrm{O} \\
\delta \mathrm{O}-\mathrm{P}-\mathrm{O} \\
\delta \mathrm{O}-\mathrm{P}-\mathrm{O}\end{array}$ \\
\hline 117 & 423.17 & 11.09 & 5.12 & $\begin{array}{l}5.65 \\
5.12 \\
11.51 \\
6.40\end{array}$ & $\begin{array}{l}\nu \mathrm{Ca}-\mathrm{O} \\
\nu \mathrm{Ca}-\mathrm{O} \\
\nu \mathrm{P}-\mathrm{O} \\
\delta \mathrm{O}-\mathrm{P}-\mathrm{O}\end{array}$ \\
\hline 116 & 421.99 & 8.66 & 2.61 & $\begin{array}{l}9.59 \\
11.12 \\
9.06\end{array}$ & $\begin{array}{l}\nu \mathrm{Ca}-\mathrm{O} \\
\nu \mathrm{P}-\mathrm{O} \\
\delta \mathrm{O}-\mathrm{P}-\mathrm{O}\end{array}$ \\
\hline 115 & 369.66 & 15.06 & 5.53 & 11.15 & $\nu \mathrm{Ca}-\mathrm{O}$ \\
\hline 114 & 355.73 & 11.52 & 0.82 & $\begin{array}{l}9.59 \\
5.95 \\
11.57\end{array}$ & $\begin{array}{l}\nu \mathrm{Ca}-\mathrm{O} \\
\nu \mathrm{P}-\mathrm{O} \\
\delta \mathrm{O}-\mathrm{P}-\mathrm{O}\end{array}$ \\
\hline 113 & 340.98 & 7.19 & 23.89 & $\begin{array}{l}6.66 \\
8.06\end{array}$ & $\begin{array}{l}\nu \mathrm{Ca}-\mathrm{O} \\
\nu \mathrm{Ca}-\mathrm{O}\end{array}$ \\
\hline 112 & 317.66 & 6.80 & 15.69 & 10.76 & $\nu \mathrm{Ca}-\mathrm{O}$ \\
\hline 111 & 304.05 & 3.52 & 8.33 & $\begin{array}{l}5.03 \\
11.97 \\
7.77\end{array}$ & $\begin{array}{l}\nu \mathrm{Ca}-\mathrm{O} \\
\nu \mathrm{Ca}-\mathrm{O} \\
\nu \mathrm{Ca}-\mathrm{O}\end{array}$ \\
\hline 110 & 292.33 & 9.41 & 8.59 & $\begin{array}{l}11.06 \\
7.94\end{array}$ & $\begin{array}{l}\nu \mathrm{Ca}-\mathrm{O} \\
\nu \mathrm{Ca}-\mathrm{O}\end{array}$ \\
\hline 109 & 286.40 & 5.74 & 5.70 & $\begin{array}{l}6.80 \\
14.72 \\
5.16 \\
5.76\end{array}$ & $\begin{array}{l}\nu \mathrm{Ca}-\mathrm{O} \\
\nu \mathrm{Ca}-\mathrm{O} \\
\nu \mathrm{Ca}-\mathrm{O} \\
\delta \mathrm{O}-\mathrm{P}-\mathrm{O}\end{array}$ \\
\hline 108 & 272.61 & 2.05 & 5.95 & $\begin{array}{l}7.47 \\
7.25 \\
15.90\end{array}$ & $\begin{array}{l}\nu \mathrm{Ca}-\mathrm{O} \\
\nu \mathrm{Ca}-\mathrm{O} \\
\nu \mathrm{P}-\mathrm{O}\end{array}$ \\
\hline 107 & 255.65 & 13.24 & 8.95 & $\begin{array}{l}19.79 \\
9.60 \\
10.74 \\
10.00 \\
5.35\end{array}$ & $\begin{array}{l}\nu \mathrm{Ca}-\mathrm{O} \\
\nu \mathrm{Ca}-\mathrm{O} \\
\nu \mathrm{P}-\mathrm{O} \\
\delta \mathrm{O}-\mathrm{P}-\mathrm{O} \\
\delta \mathrm{Ca}-\mathrm{O}-\mathrm{P}\end{array}$ \\
\hline
\end{tabular}




\begin{tabular}{|c|c|c|c|c|c|}
\hline 106 & 241.07 & 7.20 & 8.21 & $\begin{array}{l}14.14 \\
12.51 \\
6.30\end{array}$ & $\begin{array}{l}\nu \mathrm{Ca}-\mathrm{O} \\
\nu \mathrm{Ca}-\mathrm{O} \\
\delta \mathrm{O}-\mathrm{P}-\mathrm{O}\end{array}$ \\
\hline 105 & 235.74 & 10.58 & 3.14 & $\begin{array}{l}6.80 \\
7.49\end{array}$ & $\begin{array}{l}\nu \mathrm{Ca}-\mathrm{O} \\
\delta \mathrm{O}-\mathrm{P}-\mathrm{O}\end{array}$ \\
\hline 104 & 225.17 & 16.02 & 0.14 & $\begin{array}{l}13.08 \\
9.48 \\
22.76 \\
6.19\end{array}$ & $\begin{array}{l}\nu \mathrm{Ca}-\mathrm{O} \\
\nu \mathrm{Ca}-\mathrm{O} \\
\delta \mathrm{O}-\mathrm{P}-\mathrm{O} \\
\delta \mathrm{O}-\mathrm{P}-\mathrm{O}\end{array}$ \\
\hline 103 & 209.83 & 8.97 & 5.44 & $\begin{array}{l}5.10 \\
5.86 \\
9.23 \\
11.57\end{array}$ & $\begin{array}{l}\nu \mathrm{Ca}-\mathrm{O} \\
\nu \mathrm{Ca}-\mathrm{O} \\
\delta \mathrm{O}-\mathrm{P}-\mathrm{O} \\
\delta \mathrm{O}-\mathrm{P}-\mathrm{O}\end{array}$ \\
\hline 102 & 194.48 & 13.04 & 0.62 & 12.52 & $\nu \mathrm{Ca}-\mathrm{O}$ \\
\hline 101 & 181.53 & 9.78 & 1.31 & 9.69 & $\nu \mathrm{Ca}-\mathrm{O}$ \\
\hline 100 & 171.95 & 9.28 & 6.12 & $\begin{array}{l}16.25 \\
5.14\end{array}$ & $\begin{array}{l}\nu \mathrm{Ca}-\mathrm{O} \\
\nu \mathrm{P}-\mathrm{O}\end{array}$ \\
\hline 99 & 169.68 & 5.02 & 0.80 & $\begin{array}{l}10.10 \\
19.33 \\
6.06\end{array}$ & $\begin{array}{l}\nu \mathrm{Ca}-\mathrm{O} \\
\delta \mathrm{O}-\mathrm{P}-\mathrm{O} \\
\delta \mathrm{Ca}-\mathrm{O}-\mathrm{P}\end{array}$ \\
\hline 98 & 151.80 & 10.92 & 2.32 & $\begin{array}{l}8.94 \\
7.00 \\
8.09 \\
7.01 \\
9.02 \\
5.84\end{array}$ & $\begin{array}{l}\nu \mathrm{Ca}-\mathrm{O} \\
\nu \mathrm{Ca}-\mathrm{O} \\
\delta \mathrm{O}-\mathrm{P}-\mathrm{O} \\
\delta \mathrm{O}-\mathrm{P}-\mathrm{O} \\
\delta \mathrm{Ca}-\mathrm{O}-\mathrm{P} \\
\delta \mathrm{Ca}-\mathrm{O}-\mathrm{P}\end{array}$ \\
\hline 97 & 145.94 & 12.65 & 7.40 & 15.08 & $\delta \mathrm{O}-\mathrm{P}-\mathrm{O}$ \\
\hline 96 & 139.23 & 11.06 & 4.32 & $\begin{array}{l}7.07 \\
5.93 \\
9.22\end{array}$ & $\begin{array}{l}\nu \mathrm{Ca}-\mathrm{O} \\
\nu \mathrm{Ca}-\mathrm{O} \\
\delta \mathrm{O}-\mathrm{P}-\mathrm{O}\end{array}$ \\
\hline 95 & 130.43 & 11.11 & 6.66 & $\begin{array}{l}6.46 \\
10.63 \\
6.72\end{array}$ & $\begin{array}{l}\delta \mathrm{O}-\mathrm{P}-\mathrm{O} \\
\delta \mathrm{Ca}-\mathrm{O}-\mathrm{P} \\
\delta \mathrm{Ca}-\mathrm{O}-\mathrm{P}\end{array}$ \\
\hline 94 & 124.67 & 7.17 & 2.19 & $\begin{array}{l}7.79 \\
13.80\end{array}$ & $\begin{array}{l}\nu \mathrm{Ca}-\mathrm{O} \\
\nu \mathrm{Ca}-\mathrm{O}\end{array}$ \\
\hline 93 & 110.53 & 16.91 & 7.36 & 10.70 & $\nu \mathrm{Ca}-\mathrm{O}$ \\
\hline 92 & 107.36 & 11.57 & 6.86 & $\begin{array}{l}20.61 \\
5.03 \\
10.72\end{array}$ & $\begin{array}{l}\nu \mathrm{Ca}-\mathrm{O} \\
\delta \mathrm{O}-\mathrm{P}-\mathrm{O} \\
\delta \mathrm{Ca}-\mathrm{O}-\mathrm{P}\end{array}$ \\
\hline 91 & 98.72 & 2.40 & 2.49 & $\begin{array}{l}6.78 \\
7.99 \\
7.09 \\
9.77\end{array}$ & $\begin{array}{l}\nu \mathrm{Ca}-\mathrm{O} \\
\nu \mathrm{P}-\mathrm{O} \\
\delta \mathrm{O}-\mathrm{P}-\mathrm{O} \\
\delta \mathrm{Ca}-\mathrm{O}-\mathrm{P}\end{array}$ \\
\hline 90 & 92.58 & 9.77 & 3.39 & 18.34 & $\nu \mathrm{Ca}-\mathrm{O}$ \\
\hline 89 & 82.11 & 7.89 & 2.26 & 10.22 & $\chi \mathrm{Ca}-\mathrm{O}$ \\
\hline 88 & 11.92 & 8.00 & 0.57 & 24.46 & $\chi \mathrm{P}-\mathrm{O}$ \\
\hline
\end{tabular}




\title{
References
}

1. Inorganic Phosphate Materials, ed. by Kanazava T. Elsevier Science Publishing B.V., 1989.

2. Shpak A.P., Karbovskii V.L., Trachevskii V.V. Apatites Kiev, Akademperiodika, 2002 (in Russian).

3. Shpak A.P., Karbovskii V.L., Trachevskii V.V., Didenko R.V., Kurgan N.A., Smolyak S.S., Metallophysics and modern technologies, 2003, 25, No. 10, 1303 (in Russian).

4. Pilipenko V.V., Moseke C., Boeling O., Sukhodub L.F., Sulkio-Cleff B., Reports of National Academy of Sciences of Ukraine, 2002, 5, 123.

5. Pilipenko V.V., Sukhodub L.B., Moseke C., Sulkio-Cleff B., Visnyk Kharkivs'kogo Universitetu, 2002, 2, 126 .

6. Sukhodub L.F., Pilipenko V.V., Moseke C., Kalinkevich A.N., Sukhodub L.B., Boeling O., Sulkio-Cleff B., Reports of the National Academy of Sciences of Ukraine, 2000, 4, 128.

7. Fritsh H-W., Shmidt I., Kohl P., Jungclas H., Duschner H., Int. J. Mass Spectrom. Ion Process, 1993, 126, 196

8. Slosarczyk A., Piekarczyk J., Ceramica International, 1999, 25, 565.

9. Zeng H., Lancefield W.R., Biomaterials, 2000, 21, 30.

10. Schmidt M.W., Baldridge K.K., Boatz J.A., Elbert S.T., Gordon M.S., Jensen J.H., Koseki S., Matsunaga N., Nguyen K.A., Su S., Windus T.L., Dupuis M., Montgomery J.A., Jr., General Atomic and Molecular Electronic Structure System., J. Computational Chem., 1993, 14, No. 11, 1363. http://www.ms.gameslab/gov/GAMES/pcgamess.shtml

11. Khavryutchenko V., Garapon J., Poumellec B., Modelling Simul. Mater. Sci. Eng., 2002, 9, 483.

12. Nakamoto K., Infrared and Raman Spectra of Inorganic and Coordination Compounds, Mir, Moscow, 1991, 536 (in Russian).

13. Treboux G., Kanazaki N., Onuma K., Ito A., J. Phys. Chem. A, 1999, 103, 8120.

14. Khavryutchenko A.V., Khavryutchenko V.D., Stochastic global optimisation for the space structure: quantum chemical simulation of the relaxation and thermal simulation process, 10-th International Seminar on "Neutron Scattering Investigations in Condensed Matter", Poznan, May 2003.

15. Mitchell P.C.H., Parker S.F., Simkiss K., Simmons J., Taylor M.G., J. Inorganic Biochem., 1996, 62, No. 3, 197.

\section{Ab initio моделювання кальцій-фосфатних кластерів і їх вібраційних спектрів}

\author{
І.Є.Болдескул ${ }^{1}$, Л.Ф.Суходуб ${ }^{1}$, О.М.Калінкевич ${ }^{1}$, В.Д.Хаврюченко ${ }^{2}$ \\ ${ }^{1}$ Інститут прикладної фізики НАНУ, вул. Петропавлівська, 58, м. Суми, Україна, 40030 \\ 2 Інститут сорбції та проблем ендоекології НАНУ, вул. генерала Наумова, 13, м. Київ, Україна, 03164
}

Отримано 29 березня 2006 р., в остаточному вигляді - 20 червня 2006 р.

Кластери кальцій-фосфату та гідроксикальцій-фосфату, які моделюють елементарні одиниці аморфної фази, а також їх вібраційні спектри були розраховані за допомогою ab initio квантово-хімічного методу з використанням програмного коду GAMESS. Було проведено нормально-координатний аналіз для фосфатного аніону, трикальційфосфату та гідроксилапатиту. Розраховані 1Ч-спектри та спектри непружного розсіювання нейтронів були співставлені з експериментальними даними. Показано, що у рамках запропонованого підходу вібраційна спектроскопія є надійним методом для верифікації структур, що знайдені методом квантово-хімічних розрахунків.

Ключові слова: молекулярна симуляція, кластерне наближення, фосфат кальція, гідроксилапатит, нормально-координатний аналіз

PACS: 31.15.Ar, 61.46.Bc, 87.68.+z, 87.15.-v 
